\title{
Tolbutamide potentiates the volume-regulated anion channel current in rat pancreatic beta cells
}

\author{
L. Best ${ }^{1,2} \cdot$ S. Davies ${ }^{3} \cdot$ P. D. Brown ${ }^{3}$ \\ ${ }^{1}$ Department of Medicine, University of Manchester, UK \\ ${ }^{2}$ Multipurpose Building, Manchester Royal Infirmary, Manchester, UK \\ ${ }^{3}$ School of Biological Sciences, University of Manchester, UK
}

\section{Abstract}

Aims/hypothesis. Hypoglycaemic sulphonylureas are thought to stimulate insulin release by binding to a sulphonylurea receptor, closing $\mathrm{K}_{\text {АTP }}$ channels and inducing electrical activity. However, the fact that these drugs stimulate insulin release at high glucose concentrations where $\mathrm{K}_{\text {ATP }}$ channels are closed suggests additional ionic actions. The aim of this study was to test the hypothesis that sulphonylureas influence the current of the glucose- and volume-regulated anion channel. Methods. Electrical and ion-channel activity were recorded in isolated rat beta cells using the patchclamp technique. ${ }^{86} \mathrm{Rb}^{+}$efflux was measured using intact islets. Beta cell volume was measured using a video-imaging technique.

Results. In the absence of glucose, tolbutamide $(100 \mu \mathrm{mol} / \mathrm{l})$ transiently depolarised the cells. In the presence of glucose $(5 \mathrm{mmol} / \mathrm{l})$, tolbutamide evoked a sustained period of electrical activity, whilst at
$10 \mathrm{mmol} / 1$ glucose, the drug evoked a pronounced 'silent' depolarisation. In the absence of glucose, tolbutamide inhibited ${ }^{86} \mathrm{Rb}^{+}$efflux. However, at $10 \mathrm{mmol} / \mathrm{l}$ glucose, tolbutamide induced a transient stimulation of efflux. Tolbutamide potentiated the whole-cell volume-regulated anion conductance in a glucose-dependent manner with an $\mathrm{EC}_{50}$ of $85 \mu \mathrm{mol} / \mathrm{l}$. In single channel recordings, tolbutamide increased the channel-open probability. Tolbutamide caused beta cell swelling in the presence of glucose, but not in its absence.

Conclusions/interpretation. Tolbutamide can induce beta cell electrical activity by potentiating the glucose- and volume-regulated anion channel current. This effect is probably not due to a direct effect of the drug on the channel, but could be secondary to a metabolic action in the beta cell.

Keywords Electrical activity - Islet - Pancreatic beta cell $\cdot$ Sulphonylurea Volume-regulated anion channel
Received: 8 April 2004 / Accepted: 22 July 2004

Published online: 24 November 2004

C) Springer-Verlag 2004

\section{Best (®)}

Multipurpose Building, Manchester Royal Infirmary,

Oxford Road, Manchester, M13 9WL, UK

E-mail: Len.Best@cmmc.nhs.uk

Tel.: +44-161-2764338, Fax: +44-161-2744833

Abbreviations: DIDS, 4,4'-dithiocyanatostilbene-2,2'disulphonic acid $\cdot$ FOR, fractional outflow rate $\cdot$ NPPB, 5-nitro-2-(3-phenylpropylamino) benzoic acid · VRAC, volume-regulated anion channel

\section{Introduction}

Sulphonylureas are commonly used for the treatment of type 2 (non-insulin-dependent) diabetes. The hypoglycaemic action of these drugs is attributed to a direct stimulatory effect on insulin release from the pancreatic beta cell. It is generally accepted that the insulinotropic action of sulphonylureas is primarily the result of binding to a high affinity sulphonylurea receptor (SUR1) that forms one subunit of the functional $\mathrm{K}_{\mathrm{ATP}}$ channel in the beta cell plasma membrane. Binding of the drug results in channel inhibition, leading to a depolarisation of the membrane potential, and hence electrical activity, and a rise in cytosolic $\left[\mathrm{Ca}^{2+}\right]$ (for reviews see $[1,2]$ ). In addition to this effect on 
beta cell electrical activity, it has been suggested that sulphonylureas can exert a stimulatory effect on insulin release at a 'distal' site in the exocytotic pathway [3]. In essence, it was reported that sulphonylureas potentiate $\mathrm{Ca}^{2+}$-induced exocytosis in voltage-clamped mouse beta cells, as assessed by measuring plasma membrane capacitance. This action was thought to involve the binding of the drugs to a low-affinity $65 \mathrm{M}_{\mathrm{r}}$ binding site that is functionally associated with a chloride channel in the secretory granule membrane, resulting in increased transport of $\mathrm{Cl}^{-}$with concomitant granule acidification. The latter effect was suggested to render the granules 'release competent'. However, using measurements of plasma membrane capacitance and insulin release, a different laboratory reported that sulphonylureas acted by raising cytosolic $\left[\mathrm{Ca}^{2+}\right]$ alone, and not by potentiating the action of $\mathrm{Ca}^{2+}$ on exocytosis [4]. Thus, the existence of a distal site of sulphonylurea action in the beta cell is uncertain at present.

The therapeutic action of sulphonylureas depends upon their ability to stimulate insulin release at raised glucose concentrations. Since direct recordings of $\mathrm{K}_{\mathrm{ATP}}$ channel activity indicate that these channels are closed at glucose concentrations of $5 \mathrm{mmol} / \mathrm{l}$ and above [5], it is likely that sulphonylureas can exert additional ionic effects on the beta cell. The aim of the present study was to test the hypothesis that sulphonylureas influence the glucose- and volume-regulated anion channel (VRAC) current previously described in beta cells $[6,7]$.

\section{Materials and methods}

Materials. Collagenase (type 4) was obtained from Worthington (Cambridge Biosciences, Cambridge, UK). We obtained 5-nitro-2-(3-phenylpropylamino) benzoic acid (NPPB) from RBI Research (Natick, Mass., USA). Tolbutamide, glibenclamide, diazoxide, 4,4'-dithiocyanatostilbene-2,2'-disulphonic acid (DIDS) and all other chemicals were supplied by Sigma Chemicals (Poole, $\mathrm{UK}$ ). ${ }^{86} \mathrm{RbCl}$ and $\mathrm{D}-\left[\mathrm{U}^{14} \mathrm{C}\right]$ glucose were obtained from the Radiochemical Centre (Amersham, UK).

Islet and beta cell preparation. Pancreatic islets were prepared from Sprague-Dawley rats (weight 300-350 g, either sex; obtained from the University of Manchester Biological Services Unit) by collagenase digestion. For electrophysiological and cell volume experiments, islets were dispersed into single cells by a brief (3-4 min) incubation in $\mathrm{Ca}^{2+}$-free medium consisting of $120 \mathrm{mmol} / \mathrm{l} \mathrm{NaCl}, 5 \mathrm{mmol} / \mathrm{l} \mathrm{KCl}, 2 \mathrm{mmol} / \mathrm{l} \mathrm{MgSO}$, $4 \mathrm{mmol} / \mathrm{l}$ glucose, $1 \mathrm{mmol} / \mathrm{l}$ EGTA, $1 \%(\mathrm{w} / \mathrm{v}) \mathrm{BSA}$ and $25 \mathrm{mmol} / \mathrm{l}$ Hepes- $\mathrm{NaOH}$ ( $\mathrm{pH}$ 7.4). Cells were centrifuged at $100 \mathrm{~g}$ for $5 \mathrm{~min}$, re-suspended in Hepes-buffered Minimal Essential Medium (MEM; Gibco, Paisley, UK), plated onto 30$\mathrm{mm}$ diameter polystyrene dishes, and cultured in humidified air at $37^{\circ} \mathrm{C}$ for $2-10$ days. Beta cells were identified by their size (beta cells are larger than non-beta cells), their granular appearance and, where possible, by their response to glucose. The standard incubation medium used for islet cell preparation and incubations consisted of $120 \mathrm{mmol} / 1 \mathrm{NaCl}, 5 \mathrm{mmol} / \mathrm{l} \mathrm{KCl}$,
$1 \mathrm{mmol} / \mathrm{l} \mathrm{MgSO}{ }_{4}, 1 \mathrm{mmol} / 1 \mathrm{NaH}_{2} \mathrm{PO}_{4}, 1.2 \mathrm{mmol} / \mathrm{l} \mathrm{CaCl}{ }_{2}$, $25 \mathrm{mmol} / \mathrm{l}$ Hepes- $\mathrm{NaOH}$ (pH 7.4) and glucose at the required concentration. Electrophysiological experiments were performed at $28-30{ }^{\circ} \mathrm{C}$, whereas ${ }^{86} \mathrm{Rb}^{+}$efflux, and measurements of cell volume and $\mathrm{D}-\left[\mathrm{U}^{14} \mathrm{C}\right]$ glucose metabolism were carried out at $37^{\circ} \mathrm{C}$.

Assessment of beta cell electrical activity. Cells were superfused with incubation medium at a rate of approximately $2 \mathrm{ml} / \mathrm{min}$. Beta cell membrane potential was recorded from single beta cells using the 'perforated patch' technique with a List EPC-7 amplifier (List, Darmstadt, Germany) in currentclamp mode [8]. The pipette solution consisted of $60 \mathrm{mmol} / \mathrm{l}$ $\mathrm{K}_{2} \mathrm{SO}_{4}, 10 \mathrm{mmol} / \mathrm{l} \mathrm{KCl}, 10 \mathrm{mmol} / \mathrm{l} \mathrm{NaCl}, 10 \mathrm{mmol} / \mathrm{l}$ Hepes$\mathrm{NaOH}(\mathrm{pH} 7.2)$ and $240 \mu \mathrm{g} / \mathrm{ml}$ amphotericin B. Series resistance was $<25 \mathrm{M} \Omega$ and whole-cell capacitance was within the range $8-12 \mathrm{pF}$.

Measurement of $86 R b+$ efflux. We measured the fractional outflow rate (FOR) of ${ }^{86} \mathrm{Rb}^{+}$from pre-loaded perifused islets as an index of net islet cell $\mathrm{K}^{+}$permeability. Groups of 50 islets in $0.2 \mathrm{ml}$ of incubation medium were pre-incubated for $90 \mathrm{~min}$ with $740 \mathrm{KBq}{ }^{86} \mathrm{RbCl}$, washed, and then perifused at a rate of $1 \mathrm{ml} / \mathrm{min}$. Following a 'wash-out' period of $20 \mathrm{~min}$, the radioactivity content of $1-\mathrm{ml}$ aliquots of perifusate was counted using a liquid scintillation counter.

Measurement of VRAC activity: whole-cell level. Whole-cell current was measured at a holding potential of $-65 \mathrm{mV}$ using the perforated patch technique. The pipette solution was similar to that described above except that $\mathrm{K}^{+}$was replaced by $\mathrm{Cs}^{+}$ in order to eliminate $\mathrm{K}^{+}$currents. The inward current recorded under similar conditions has previously been described $[9,10]$, and is thought to represent the VRAC activity. In order to quantify changes in VRAC activity, mean current amplitudes were measured from 60-second segments of recording under various conditions using pClamp6 software (Axon Instruments, Foster City, Calif., USA) [10]. Single isolated beta cells were used for these experiments in order to avoid contaminating currents from adjacent electrically coupled cells.

Measurement of VRAC activity: single channel level. Activity of the VRAC at the single channel level was recorded using the cell-attached configuration of the patch-clamp technique essentially as described previously [11, 12]. Diazoxide $(150 \mu \mathrm{mol} / \mathrm{l})$ was included in the bath solution to clamp the cell membrane potential close to $\mathrm{E}_{\mathrm{K}}$ (see below) and to minimise changes in the membrane potential. The standard pipette solution was designed to block $\mathrm{K}^{+}$currents, eliminate $\mathrm{Na}^{+}$and $\mathrm{Ca}^{2+}$ currents, and optimise inward $\mathrm{Cl}^{-}$currents, and consisted of $60 \mathrm{mmol} / \mathrm{l} \mathrm{Cs} \mathrm{SO}_{4}, 40 \mathrm{mmol} / \mathrm{l} \mathrm{CsCl}, 1 \mathrm{mmol} / \mathrm{l} \mathrm{MgCl}$ and $10 \mathrm{mmol} / \mathrm{l}$ Hepes-CsOH (pH 7.4). At a pipette potential of $0 \mathrm{mV}$, channel openings generated an inward current that was recorded as a downward deflection in all cases. Patch pipettes had a resistance of approximately $1 \mathrm{M} \Omega$ when filled with the standard pipette solution. The membrane potential of the cell was occasionally measured at the end of the recording by applying suction to the patch and switching the amplifier to current-clamp immediately upon forming the whole-cell configuration. Using this method on 20 cells, a value of $58.4 \pm 1.3 \mathrm{mV}$ was obtained. Current recordings were filtered at $30 \mathrm{~Hz}$ and stored for subsequent analysis. Channel activity is expressed as $n p$, where $n$ is the number of channels (or conductance states) and $p$ is open probability. This value was calculated from current-amplitude histograms constructed from 60-second segments of recording and fitted to Gaussian distributions by the 'least squares' method, again using pClamp6 
software. Mean channel-open and channel-closed times were calculated by fitting single exponential curves to frequency histograms, again obtained from 60-second segments of recording. A limited number of recordings were made from perforated membrane vesicles and from excised patches (pulled from cells under perforated patch and cell-attached configurations respectively).

Cell volume measurements. Changes in beta cell volume were monitored by a video-imaging technique as described previously [13]. Cell volume is expressed as relative cell volume (i.e. normalised with respect to the volume observed during the control period prior to the addition of tolbutamide). The area under each curve (plus or minus glucose) was calculated during the period of exposure to tolbutamide and analysed for significant differences using an unpaired t test.

Islet glucose metabolism. The production of acidic glucose metabolites from glucose was measured essentially as described previously [14]. Briefly, groups of 50 islets were incubated with $370 \mathrm{KBq} \mathrm{D}-\left[\mathrm{U}^{14} \mathrm{C}\right]$ glucose (total glucose concentration $5 \mathrm{mmol} / \mathrm{l}$ ) for $90 \mathrm{~min}$. Samples of incubation medium were then subjected to ion-exchange chromatography in order to separate the ${ }^{14} \mathrm{C}$-labelled acidic metabolites (principally ${ }^{14}$ C-lactate).

Statistical significance. A $p$ value of less than 0.05 was considered statistically significant.

\section{Results}

Effects of tolbutamide on beta cell electrical activity. In the first series of experiments, the perforated patch technique was used to study the effects of tolbutamide on electrical activity in rat pancreatic beta cells (Fig. 1). In the absence of glucose, the resting membrane potential was approximately $-70 \mathrm{mV}$ (Fig. 1a). Application of $100 \mu \mathrm{mol} / \mathrm{l}$ tolbutamide depolarised the cells, resulting in a burst of action potentials. However, as previously reported [5], this effect was transient under glucose-free conditions, being followed by a gradual repolarisation to a level (approximately $55 \mathrm{mV}$ ) at which action potentials were no longer apparent. The membrane potential further repolarised to around $-70 \mathrm{mV}$ upon removal of the drug.

In the presence of a substimulatory concentration of glucose $(5 \mathrm{mmol} / \mathrm{l})$ the membrane potential was approximately $-60 \mathrm{mV}$ (Fig. 1b). Under these conditions, tolbutamide evoked a sustained period of electrical activity that persisted for the duration of exposure to the drug. Again, withdrawal of tolbutamide was followed by a repolarisation.

Cells exposed to a stimulatory concentration of glucose $(10 \mathrm{mmol} / \mathrm{l})$ showed a characteristic pattern of action potentials superimposed upon a plateau depolarisation (Fig. 1c). In this case, the addition of tolbutamide caused a marked and sustained depolarisation of the cells to a level at which discrete action potentials were no longer seen ('silent' depolarisation). Subsequent removal of the sulphonylurea was followed by a marked and prolonged period of hyperpo-
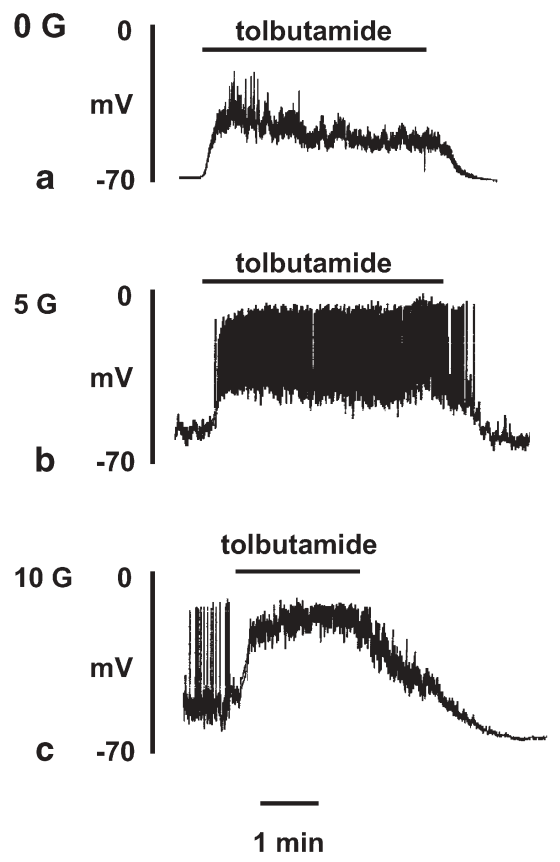

Fig. 1. Perforated patch recordings of electrical activity in rat pancreatic beta-cells in response to the application of tolbutamide $(100 \mu \mathrm{mol} / 1$, indicated by the horizontal line $)$ in the presence of 0 (a) $5 \mathrm{mmol} / \mathrm{l}$ (b) or $10 \mathrm{mmol} / \mathrm{l}$ (c) glucose. The recordings are representative of at least four experiments with similar results

larisation with a corresponding absence of electrical activity, despite the continued presence of the stimulatory glucose concentration. The cause of this hyperpolarisation 'off effect' is unclear, although a rebound increase in net $\mathrm{K}^{+}$permeability $\left({ }^{86} \mathrm{Rb}^{+}\right.$efflux) has been reported upon removal of tolbutamide [15], possibly reflecting $\mathrm{K}_{\mathrm{ATP}}$ channel activation due to reduced intracellular ATP levels [16].

$86 R b+$ efflux. The next series of experiments investigated the effects of tolbutamide on the efflux of ${ }^{86} \mathrm{Rb}^{+}$ from pre-loaded perifused islets, commonly used as an index of net islet cell $\mathrm{K}^{+}$permeability (Fig. 2). In the absence of glucose, the addition of $100 \mu \mathrm{mol} / \mathrm{l}$ tolbutamide caused a rapid and marked $(p<0.01$ after $1 \mathrm{~min}$ ) reduction in ${ }^{86} \mathrm{Rb}^{+} \mathrm{FOR}$, presumably due to inhibition of $\mathrm{K}_{\mathrm{ATP}}$ channel activity. In the presence of $10 \mathrm{mmol} / \mathrm{l}$ glucose, ${ }^{86} \mathrm{Rb}^{+}$FOR was significantly $(p<0.001)$ lower than in its absence at all time points, again reflecting $\mathrm{K}_{\text {ATP }}$ channel inhibition by the hexose. However, under these conditions, the application of tolbutamide did not further reduce ${ }^{86} \mathrm{Rb}^{+}$FOR. Instead, the sulphonylurea evoked a transient, significant $(p<0.02$ after $1 \mathrm{~min})$ stimulation of ${ }^{86} \mathrm{Rb}^{+}$efflux. Clearly, this effect of tolbutamide cannot be explained by $\mathrm{K}_{\mathrm{ATP}}$ channel inhibition, but is likely to be a secondary response to depolarisation of the plasma membrane, presumably due to an additional ionic effect of the drug. 


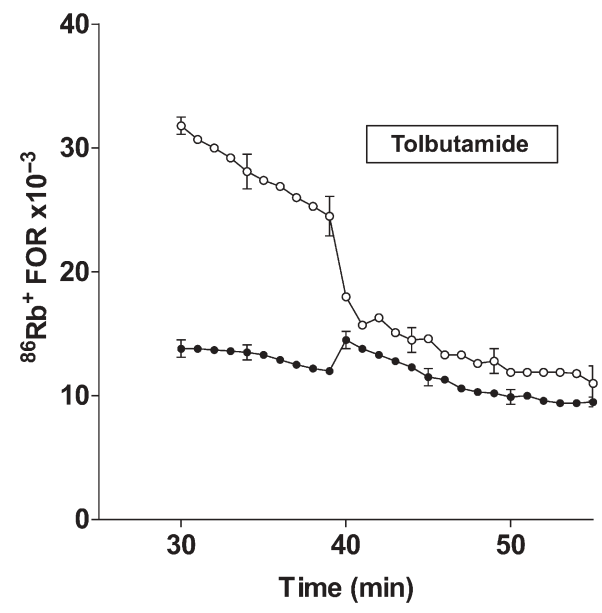

Fig. 2. Effect of tolbutamide $(100 \mu \mathrm{mol} / \mathrm{l})$ on the FOR of ${ }^{86} \mathrm{Rb}^{+}$ from pre-loaded rat islets perifused in the presence (filled circles) or absence (empty circles) of $10 \mathrm{mmol} / \mathrm{l}$ glucose. Data points show the means \pm SEM of four experiments

VRAC activity: whole-cell recordings. We next investigated whether changes in VRAC activity could explain the $\mathrm{K}_{\text {ATP }}$ channel-independent ionic action of tolbutamide. Whole-cell recordings were made from cells voltage-clamped at $-65 \mathrm{mV}$ using the perforated patch recording technique. Under such conditions, VRAC activation generates a noisy inward current with occasional discrete channel events $[9,10]$.

In the absence of glucose, the current amplitude was low and was not significantly affected by the application of tolbutamide $(100 \mu \mathrm{mol} / \mathrm{l})$ (Fig. 3). In agreement with a previous study [10], the mean amplitude of the current increased with increasing concentrations of glucose. In the presence of glucose, the application of tolbutamide was found to induce a significant, reversible increase in mean amplitude of this current. As shown in Figure 4, in the presence of an intermediate concentration of glucose $(7.5 \mathrm{mmol} / \mathrm{l})$, potentiation of the VRAC current by tolbutamide was concentration-dependent between 5 and $400 \mu \mathrm{mol} / \mathrm{l}$, with an apparent $\mathrm{EC}_{50}$ of $85 \mu \mathrm{mol} / \mathrm{l}$.

VRAC activity: single channel recordings. Cell-attached recordings of VRAC activity were made from beta cells in the presence of diazoxide $(150 \mu \mathrm{mol} / \mathrm{l})$ in order to clamp the cell membrane potential close to $\mathrm{E}_{\mathrm{K}}$. Initial perforated patch experiments were carried out in current-clamp mode to confirm that tolbutamide did not depolarise the cells under such conditions (results not shown but see [17]).

The Figure 5a shows two typical recordings of an inward channel current that has previously been suggested to be that of the VRAC $[11,12]$. In the presence of 10 or $5 \mathrm{mmol} / \mathrm{l}$ glucose, the application of tolbutamide (20 or $100 \mu \mathrm{mol} / \mathrm{l}$ respectively) further activated the channel current in a reversible manner. Potentiation of the VRAC current by tolbutamide con- a

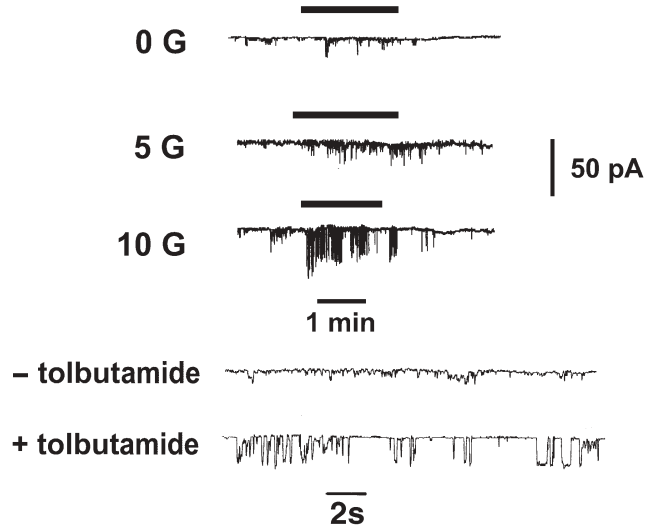

b

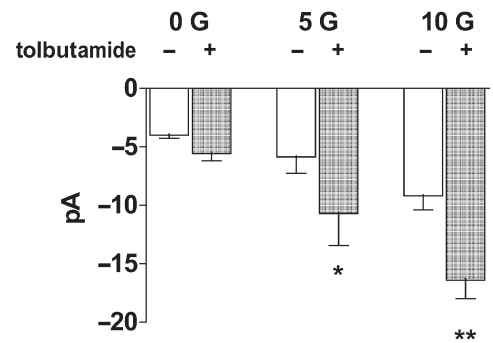

Fig. 3 a. Perforated patch recordings from rat pancreatic beta cells voltage-clamped at $-65 \mathrm{mV}$. Tolbutamide $(100 \mu \mathrm{mol} / \mathrm{l})$ was applied for the duration of the bar drawn above each trace in the presence of 0,5 or $10 \mathrm{mmol} / \mathrm{l}$ glucose $(\mathrm{G})$. The lower two traces show expanded recordings in the presence of $10 \mathrm{mmol} / \mathrm{l}$ glucose. b. Mean current amplitudes $( \pm \mathrm{SEM})$ measured in 60-second segments of recording at different concentrations of glucose in the absence and presence of $100 \mu \mathrm{mol} / \mathrm{l}$ tolbutamide. The data are derived from 6-14 cells. $* p<0.05$ and $* * p<0.01$ vs 0 tolbutamide at the same glucose concentration by paired $t$ test

sisted of a concentration-dependent increase in channel-open probability $(n p)$, with no significant effect on channel amplitude (Fig. 5b). A maximum concentration of $200 \mu \mathrm{mol} / \mathrm{l}$ tolbutamide was used in these experiments since higher concentrations were found to depolarise the cells, even in the presence of diazoxide.

The increase in channel-open probability evoked by the sulphonylurea $(100 \mu \mathrm{mol} / \mathrm{l})$ was due to an increase in the channel-open time constant $\left(\tau_{\text {open }}\right)$ from $68 \pm 24$ to $526 \pm 161 \mathrm{~ms}(n=5, p<0.02$ by paired $t$ test $)$, and a reduction in channel-closed time constant $\left(\tau_{\text {closed }}\right)$ from $1136 \pm 410$ to $60 \pm 13 \mathrm{~ms}(n=5, p<0.05)$. Tolbutamide did not influence VRAC activity in perforated membrane vesicles (i.e. an outside-out patch excised under perforated patch conditions) or in excised inside-out patches (data not shown).

Glibenclamide was found to potentiate the VRAC current in a manner similar to tolbutamide (data not shown). At the whole-cell level, mean current amplitudes in the presence of $7.5 \mathrm{mmol} / \mathrm{l}$ glucose were $4.6 \pm 1.0$ and $-11.2 \pm 1.8(n=5, p<0.05$ by paired $t$ test $)$ in the absence and presence of $5 \mu \mathrm{mol} / \mathrm{l}$ glibenclamide 


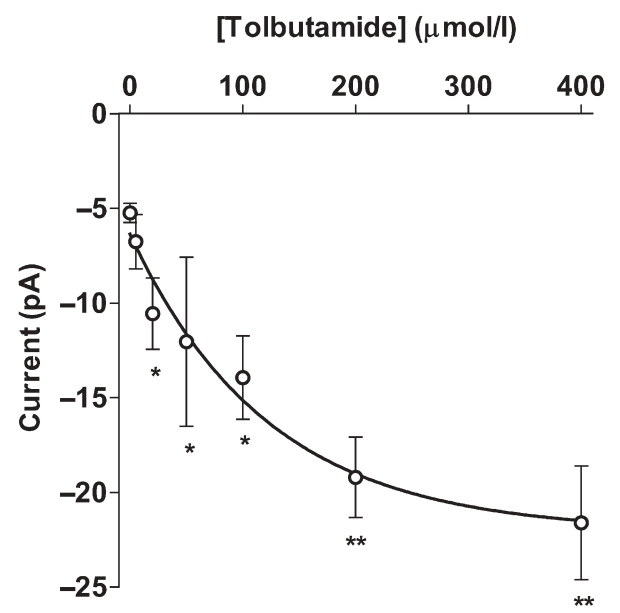

Fig. 4. Concentration-response relationship for the potentiation of whole-cell VRAC current by tolbutamide in the presence of $7.5 \mathrm{mmol} / \mathrm{l}$ glucose. The data represent mean current amplitudes $( \pm$ SEM) measured in 60 -second segments of recordings derived from $6-20$ cells. $* p<0.05$ and $* * p<0.01$ vs 0 tolbutamide by paired $t$ test respectively. At the single channel level $(5 \mathrm{mmol} / \mathrm{l}$ glucose), the corresponding open channel probabilities were $0.09 \pm 0.04$ and $0.56 \pm 0.04$ respectively $(n=4$, $p<0.01$ by paired $t$ test).

Beta cell volume. We next investigated whether potentiation of the VRAC current by tolbutamide was associated with changes in beta cell volume. As shown in Figure 6 , application of the drug $(100 \mu \mathrm{mol} / \mathrm{l})$ in the absence of glucose did not affect relative cell volume. However, in the presence of $10 \mathrm{mmol} / \mathrm{l}$ glucose, tolbutamide provoked a significant $(p<0.001)$ and reversible increase in relative cell volume to a maximum of approximately $7 \%$.

Production of acidic glucose metabolites. Over $90 \mathrm{~min}$, the production of ${ }^{14} \mathrm{C}$-labelled acidic metabolites from $\mathrm{D}-\left[\mathrm{U}^{14} \mathrm{C}\right]$ glucose $(5 \mathrm{mmol} / \mathrm{l})$ amounted to $3428 \pm 341 \mathrm{dpm}$ per 50 islets $(n=5)$. In the presence of $100 \mu \mathrm{mol} / 1$ tolbutamide, this value was significantly
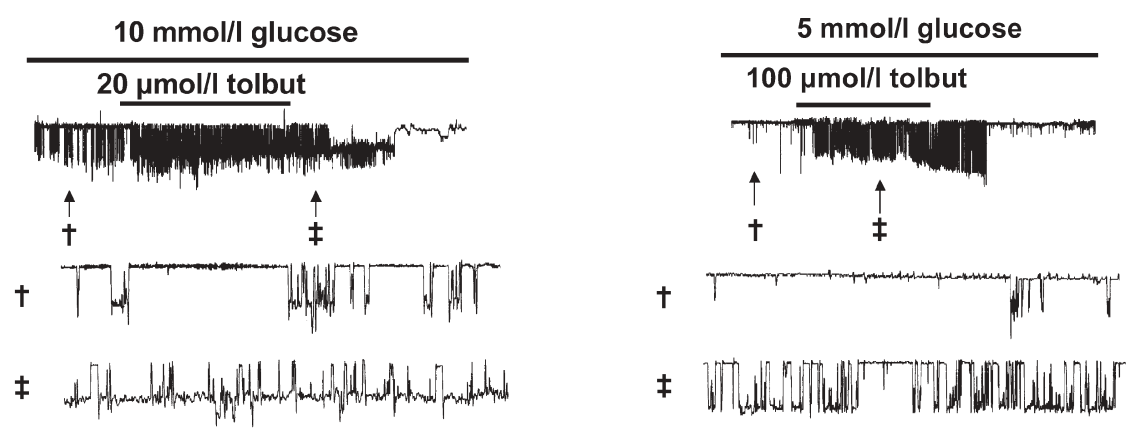

a
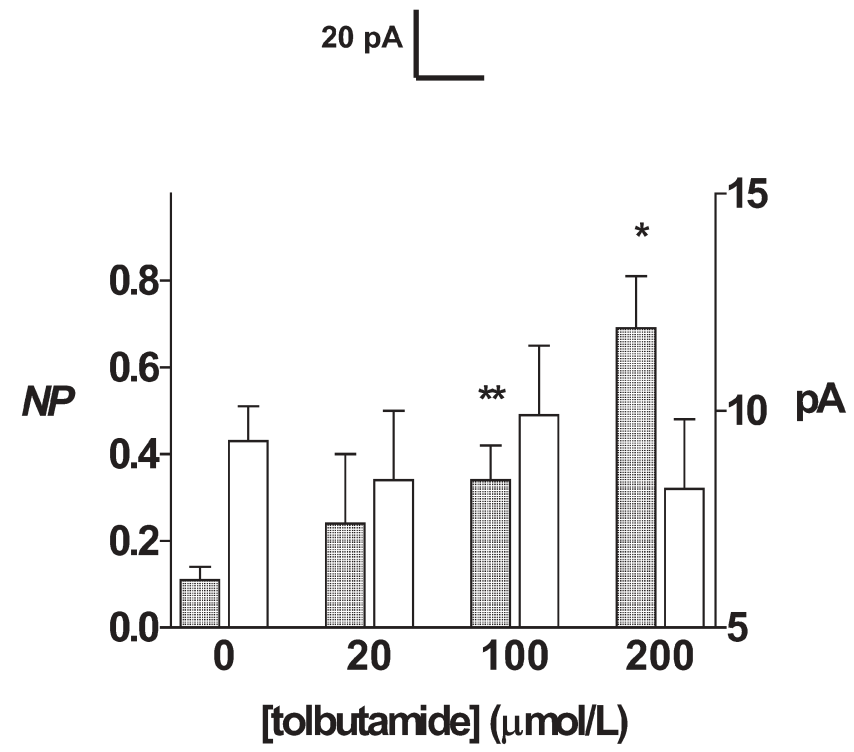

Fig. 5 a. Cell-attached recording from two rat pancreatic beta cells in the presence of $150 \mu \mathrm{mol} / \mathrm{l}$ diazoxide and 10 or $5 \mathrm{mmol} / \mathrm{l}$ glucose. Tolbutamide ( 20 or $100 \mu \mathrm{mol} / \mathrm{l}$ ) was applied for the period shown. The expanded traces show representative segments of recording in the absence $(\dagger)$ and presence $(\ddagger)$ of tolbutamide as indicated. The horizontal calibration bar represents $1 \mathrm{~min}$ or
$2 \mathrm{~s}$ in expanded traces. b. Effects of tolbutamide on VRAC open-channel probability ( $n p$, shaded bars) and single channel amplitude (pA, open bars) in the presence of $5 \mathrm{mmol} / \mathrm{l}$ glucose. The data represent means \pm SEM of recordings of the type shown in Figure 5 and were obtained from 5-16 cells. * $p<0.05$ and $* * p<0.01$ vs 0 tolbutamide by paired $t$ test 


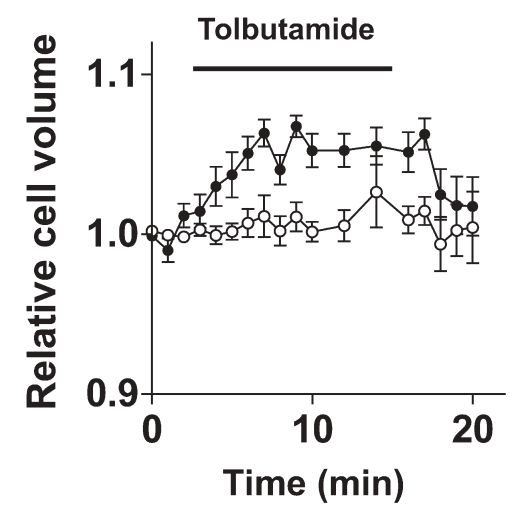

Fig. 6. Effects of tolbutamide $(100 \mu \mathrm{mol} / \mathrm{l})$ on relative cell volume in the absence (empty circles, $n=6$ ) and presence (filled circles, $n=6)$ of $10 \mathrm{mmol} / \mathrm{l}$ glucose. The areas under the two curves during the period of exposure to tolbutamide are significantly different $(p<0.001$ by unpaired $t$ test)
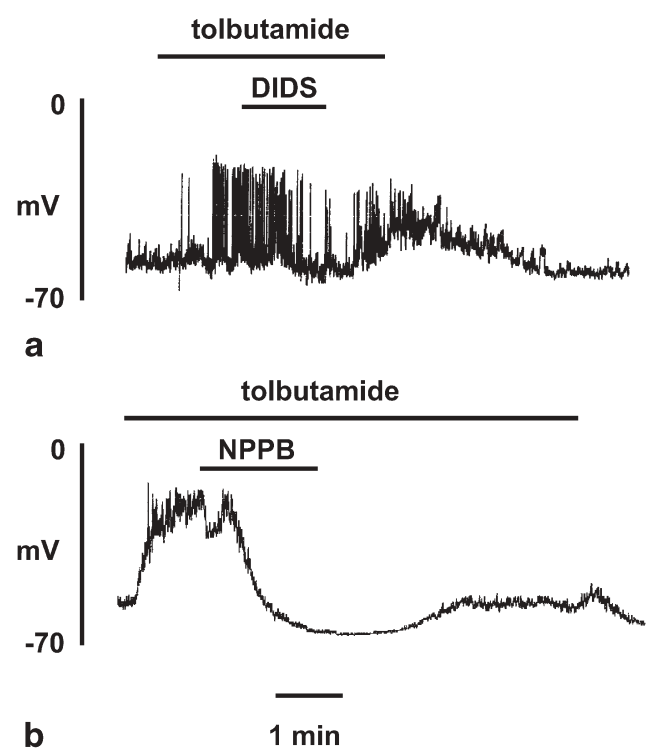

Fig. 7. Effects of the VRAC blockers DIDS (100 $\mu \mathrm{mol} / \mathrm{l})(\mathbf{a})$ and NPPB $(50 \mu \mathrm{mol} / \mathrm{l})(\mathbf{b})$ on the electrical activity elicited by $25 \mu \mathrm{mol} / \mathrm{l}$ tolbutamide in the presence of $4 \mathrm{mmol} / \mathrm{l}$ glucose. These recordings are representative of those from five and four cells respectively

$(p<0.02$ by unpaired $t$ test) increased to $5623 \pm 582$ $(n=5)$.

Effects of VRAC blockers. Based on the finding that sulphonylureas can potentiate the VRAC current, blockers of this channel should inhibit the electrical activity evoked by these drugs. It has previously been reported that the electrical activity induced by a high concentration $(100 \mu \mathrm{mol} / \mathrm{l})$ of tolbutamide is not affected by DIDS, a commonly used VRAC inhibitor [18]. To further investigate this interaction, we studied the effects of DIDS and NPPB, another VRAC blocker, using a lower concentration of tolbutamide. The application of $100 \mu \mathrm{mol} / \mathrm{l}$ DIDS gradually suppressed the electrical activity evoked by $25 \mu \mathrm{mol} / \mathrm{l}$ tolbuta- mide in a reversible manner (Fig. 7a). In the presence of NPPB $(50 \mu \mathrm{mol} / \mathrm{l})$, a marked hyperpolarisation occurred that was only partially reversible upon removal of the channel blocker (Fig. 7b).

\section{Discussion}

The reduction of hyperglycaemia in type 2 diabetes by sulphonylureas requires that the drugs are able to stimulate insulin release in the presence of elevated blood glucose concentrations. Since sulphonylureas are primarily thought to act by inhibiting $\mathrm{K}_{\text {ATP }}$ channel activity, it has been argued that their stimulatory effect at raised glucose concentrations is evidence for residual beta cell $\mathrm{K}_{\text {ATP }}$ channel activity under such conditions [19]. However, this argument ignores the possibility that these drugs are able to stimulate the beta cell by a $\mathrm{K}_{\text {АTP }}$ channel-independent mechanism.

The results of the present study indicate that sulphonylureas can indeed stimulate beta cell electrical activity in a manner that is dependent on glucose but does not involve $\mathrm{K}_{\text {ATP }}$ channel regulation. Consistent with previous results [5], in the absence of glucose (conditions under which $\mathrm{K}_{\text {ATP }}$ channel activity is raised $[5,20])$, tolbutamide produced only a transient burst of action potentials. The gradual repolarisation observed under such conditions was not due to the reactivation of $\mathrm{K}_{\mathrm{ATP}}$ channels, but instead was probably the result of activation of another $\mathrm{K}^{+}$conductance [5]. This finding emphasises that $\mathrm{K}_{\text {ATP }}$ channel inhibition by sulphonylureas is not sufficient to sustain electrical activity in the absence of glucose $[5,15,21]$. The effects of tolbutamide on beta cell depolarisation and electrical activity were most pronounced in the presence of the hexose, an observation in complete accordance with the well-documented effect of tolbutamide on insulin release, which also shows a marked dependence on glucose concentration in rat islets $[22,23$, 24]. The results of a study in which direct measurements of $\mathrm{K}_{\text {ATP }}$ channel activity were made in rat beta cells indicated that the $\mathrm{K}_{\mathrm{ATP}}$ channel is effectively blocked in the presence of glucose concentrations of $5 \mathrm{mmol} / \mathrm{l}$ or higher [5]. This suggests that tolbutamide exerts an additional ionic effect on the beta cell in the presence of normal or stimulatory concentrations of glucose.

The results of studies of ${ }^{86} \mathrm{Rb}^{+}$efflux from intact islets provide further evidence for a $\mathrm{K}_{\mathrm{ATP}}$ channel-independent ionic mechanism of sulphonylurea action. The inhibitory effect of tolbutamide on ${ }^{86} \mathrm{Rb}^{+}$efflux in the absence of glucose is fully consistent with the inhibition of $\mathrm{K}_{\text {ATP }}$ channel activity by the sulphonylurea. However, the stimulation of ${ }^{86} \mathrm{Rb}^{+}$efflux by the drug in the presence of glucose, a phenomenon that has been reported previously [15, 17], cannot be the result of $\mathrm{K}_{\text {ATP }}$ channel inhibition, and has so far remained unexplained. The simplest explanation is that the fur- 
ther depolarisation of the beta cell membrane potential by tolbutamide (as shown in Fig. 1c) generates an increased electrochemical driving force, increasing ${ }^{86} \mathrm{Rb}^{+}$efflux. The fact that the increased ${ }^{86} \mathrm{Rb}^{+}$outflow evoked by tolbutamide was transient in nature, despite the sustained depolarisation observed under comparable experimental conditions, could be explained by a rapid depletion of the relevant intracellular pool of isotope. Moreover, the ionic mechanism responsible for the depolarisation evoked by tolbutamide in the presence of glucose needs to be elucidated.

The present study provides evidence that potentiation of the VRAC by sulphonylureas could, at least in part, underlie this depolarising action. This effect of sulphonylureas was observed at the whole-cell level under voltage-clamp conditions and also at the single channel level in cell-attached recordings. The results of the latter experiments indicated that tolbutamide potentiated the VRAC current by increasing the channel-open probability. However, several aspects of the effect of tolbutamide on the VRAC current suggest that it involves an indirect effect of the drug on the anion channel. Firstly, potentiation of the current by tolbutamide was highly dependent on the presence of glucose. As reported previously $[9,10,11]$ and confirmed in the present study, the sulphonylureas had little or no effect on VRAC activity of in the absence of the sugar. Secondly, tolbutamide was observed to have no effect on VRAC activity in conventional wholecell recordings where glucose metabolism was abolished [18], and the drug did not influence channel activity in perforated membrane vesicles or excised patches. Thirdly, the ability of tolbutamide to increase the channel current in cell-attached patches suggests an indirect action, since this drug is thought to permeate very poorly into the beta cell interior [25]. Furthermore, the observed increase in beta cell volume evoked by tolbutamide in the presence of glucose also indicates an indirect mechanism of VRAC activation, since direct activation of the channel by the drug would be expected to cause a volume decrease due to accelerated osmolyte efflux.

A possible mechanism for potentiation of the VRAC current by sulphonylureas, and one which would be consistent with the above findings, is at the level of glucose metabolism in the beta cell [26]. Activation of this channel by glucose requires metabolism of the sugar [12], so any effect of these drugs on glucose metabolism would also be predicted to influence VRAC activity. Sulphonylureas have been reported to modify glucose metabolism in a number of tissues. For example, tolbutamide, glipizide and glibenclamide have been shown to increase lactate output from glucose in several cell types, including hepatocytes [27] and cardiac myocytes [28, 29]. Studies on pancreatic islets, using ${ }^{3} \mathrm{H}$-glucose as substrate, have indicated that tolbutamide and other sulphonylureas do not influence glucose utilisation $[30,31]$. Similarly, the majority of reports suggest that sulphonylureas do not significantly affect the oxidation of ${ }^{14} \mathrm{C}$-glucose or the generation of acidic glucose metabolites [30, 31, 32], at least in long-term incubations. However, an earlier study indicated that tolbutamide increased the oxidation of $\mathrm{U}-\left[{ }^{14} \mathrm{C}\right]$ glucose by $33 \%$ and doubled the output of lactate in mouse islets [33]. These findings are essentially consistent with our present findings that tolbutamide caused a $64 \%$ increase in the generation of acidic metabolites from glucose. An increased generation of glucose metabolites by sulphonylureas and the intracellular accumulation of these metabolites could explain the glucose-dependent beta cell swelling observed in response to tolbutamide, which, in turn, leads to VRAC activation (for discussion of this topic see [34]). Consistent with this possibility, we have previously demonstrated that methylglyoxal, which generates large quantities of D-lactate in islet cells [35], also causes beta cell swelling and VRAC activation [36]. The mechanism by which tolbutamide might influence glucose metabolism and, in particular, whether this effect involves SUR1, remain to be established. Clearly, more detailed investigations of the metabolic actions of sulphonylureas in islet cells are required to clarify this issue.

In line with the potentiation of the VRAC current by sulphonylureas, two commonly used blockers of this channel, DIDS and NPPB, were found to suppress tolbutamide-induced electrical activity. This result may seem inconsistent with a previous report from this laboratory indicating that electrical activity in response to a high concentration of tolbutamide was resistant to inhibition by DIDS [18]. However, it should be noted that DIDS is a relatively weak inhibitor of the VRAC, particularly the inward current component [7]. This could explain why DIDS failed to inhibit the effects of a high concentration of tolbutamide but was effective in inhibiting electrical activity evoked by a lower concentration of the sulphonylurea in the present study. A similar, though more pronounced, inhibitory effect on tolbutamide-induced electrical activity was observed with the blocker NPPB.

In conclusion, the present study provides evidence for a novel ionic action of sulphonylureas on the pancreatic beta cell. In the absence of glucose, the predominant action of the drugs is inhibition of $\mathrm{K}_{\text {АTP }}$ channels, resulting in a transient depolarisation and electrical activity. However, under conditions of normoglycaemia and hyperglycaemia, when $\mathrm{K}_{\text {ATP }}$ channel activity is minimal or absent, sulphonylureas exert an additional ionic effect consisting of a glucose-dependent activation of the VRAC, leading to a sustained depolarisation and electrical activity. The latter action is likely to underlie the reported stimulatory effect of these drugs on ${ }^{36} \mathrm{Cl}^{-}$efflux in pancreatic islets [37], and could be of considerable therapeutic relevance in the treatment of hyperglycaemia in type 2 diabetes. 
Acknowledgements. This work was supported in part by the Biotechnology and Biological Sciences Research Council (Swindon, UK).

\section{References}

1. Panten U, Schwanstecher M, Schwanstecher C (1996) Sulfonylurea receptors and mechanism of sulfonylurea action. Exp Clin Endocrinol Diabetes 104:1-9

2. Gribble FM, Reimann F (2002) Pharmacological modulation of $\mathrm{K}_{\text {ATP }}$ channels. Biochem Soc Trans 30:333-339

3. Renstrom E, Barg S, Thevenod F, Rorsman P (2002) Sulfonylurea-mediated stimulation of insulin exocytosis via an ATP-sensitive $\mathrm{K}^{+}$channel-independent action. Diabetes 51 [Suppl 1]:S33-S36

4. Mariot P, Gilon P, Nenquin M, Henquin J-C (1998) Tolbutamide and diazoxide influence insulin secretion by changing the concentration, but not the action, of cytoplasmic $\mathrm{Ca}^{2+}$ in $\beta$-cells. Diabetes 47:365-373

5. Best L (2002) Evidence that glucose-induced electrical activity in rat pancreatic $\beta$-cells does not require $\mathrm{K}_{\mathrm{ATP}}$ channel inhibition. J Membr Biol 185:193-200

6. Kinard TA, Satin LS (1995) An ATP-sensitive $\mathrm{Cl}^{-}$channel current that is activated by cell swelling, cAMP and glyburide in insulin-secreting cells. Diabetes 44:1461-1466

7. Best L, Sheader EA, Brown PD (1996) A volume-activated anion conductance in insulin-secreting cells. Pflugers Arch 431:363-370

8. Rae J, Cooper K, Gates P, Watsky M (1991) Low access resistance perforated patch recordings using amphotericin B. J Neurosci Methods 37:15-26

9. Best L (1997) Glucose and $\alpha$-ketoisocaproate induce transient inward currents in rat pancreatic beta cells. Diabetologia 40:1-6

10. Best L (2000) Glucose-sensitive conductances in rat pancreatic beta-cells: contribution to electrical activity. Biochim Biophys Acta 1468:311-319

11. Best L (1999) Cell-attached recordings of the volumesensitive anion channel in rat pancreatic B-cells. Biochim Biophys Acta 1419:248-256

12. Best L (2002) Study of a glucose-activated anion-selective channel in rat pancreatic beta-cells. Pflugers Arch 445:97-104

13. Miley HE, Sheader EA, Brown PD, Best L (1997) Glucose-induced swelling in rat pancreatic beta-cells. J Physiol 504:191-198

14. Best L, Yates AP, Meats JE, Tomlinson S (1989) Effects of lactate on pancreatic islets: Lactate efflux as a possible determinant of islet cell depolarization by glucose. Biochem J 259:507-511

15. Henquin JC (1980) Tolbutamide stimulation and inhibition of insulin release: studies of the underlying ionic mechanisms in isolated rat islets. Diabetologia 18:151-160

16. Hellman B, Idahl L-A, Danielsson A (1969) Adenosine triphosphate level of mammalian pancreatic $\beta$-cells after stimulation with glucose and hypoglycaemic sulfonylureas. Diabetes 18:509-516

17. Henquin JC, Meissner HP (1982) Opposite effects of tolbutamide and diazoxide on ${ }^{86} \mathrm{Rb}^{+}$fluxes and membrane potential in pancreatic B cells. Biochem Pharmacol 31:1407-1415

18. Best L, Benington S (1998) Effects of sulphonylureas on the volume-sensitive anion channel in rat pancreatic $\beta$-cells. Br J Pharmacol 125:874-878

19. Cook DL, Ikeuchi M (1989) Tolbutamide as mimic of glucose on $\beta$-cell electrical activity. ATP-sensitive $\mathrm{K}^{+}$chan- nels as common pathway for both stimuli. Diabetes 38: 416-421

20. Ashcroft FM, Ashcroft SJH, Harrison DE (1988) Properties of single potassium channels modulated by glucose in rat pancreatic $\beta$-cells. J Physiol 400:501-527

21. Henquin JC (1998) A minimum of fuel is necessary for tolbutamide to mimic the effects of glucose on electrical activity in pancreatic $\beta$-cells. Endocrinology 139:993998

22. Joost HG, Hasselblatt A (1979) Insulin release by tolbutamide and glibenclamide. A comparative study on the perfused rat pancreas. Naunyn Schmiedebergs Arch Pharmacol 306:185-188

23. Kadowaki S, Taminato T, Chiba T, Nozawa M, Fujita T, Norman AW (1983) Effect of tolbutamide on insulin, glucagon and somatostatin release from the diabetic rat pancreas with special reference to glucose concentration. Endocrinology 112:2187-2192

24. Zawalich WS, Zawalich KC (1988) Induction of memory in rat pancreatic islets by tolbutamide. Dependence on ambient glucose level, calcium and phosphoinositide hydrolysis. Diabetes 37:816-823

25. Hellman B, Sehlin J, Taljedal I-B (1971) The pancreatic $\beta$-cell recognition of insulin secretagogues. II. Site of action of tolbutamide. Biochem Biophys Res Commun 45: 1384-1388

26. Gylfe E, Hellman B, Sehlin J, Taljedal I-B (1984) Interaction of sulfonylurea with the pancreatic $\beta$-cell. Experientia 40:1126-1134

27. Lopez-Alarcon L, Melian E, Berbil-Bautista PR, Guijarro C, Feliu JE (1990) Modulation of glucose metabolism by sulfonylureas in primary cultures of adult rat hepatocytes. Biochem Int 21:1125-1134

28. Kramer JH, Lampson WG, Schaffer SW (1983) Effect of tolbutamide on myocardial energy metabolism. Am J Physiol 245:H313-H319

29. Schaffer SW, Tan BH, Mozaffari MS (1985) Effect of glyburide on myocardial metabolism and function. Am J Med 79:48-52

30. Kawazu S, Sener A, Couturier E, Malaisse WJ (1980) Metabolic, cationic and secretory effects of hypoglycaemic sulphonylureas in pancreatic islets. Naunyn Schmiedebergs Arch Pharmacol 312:277-283

31. Malaisse WJ, Lebrun P, Sener A (1993) Modulation of the insulinotropic action of glibenclamide and glimepiride by nutrient secretagogues in pancreatic islets from normoglycemic and hyperglycemic rats. Biochem Pharmacol 45:1845-1849

32. Gorus FK, Schuit FC, In't Veld PA, Gepts W, Pipeleers DG (1988) Interaction of sulfonylureas with pancreatic betacells. A study with glyburide. Diabetes 37:1090-1095

33. Ashcroft SJH, Hedeskov CJ, Randle PJ (1970) Glucose metabolism in mouse pancreatic islets. Biochem J 118:143-154

34. Best L, Brown PD, Tomlinson S (1997) Anion fluxes, volume regulation and electrical activity in the mammalian pancreatic $\beta$-cell. Exp Physiol 82:957-966

35. Cook LJ, Davies J, Yates AP et al. (1998) Effects of methylglyoxal on rat pancreatic $\beta$-cells. Biochem Pharmacol 55:1361-1367

36. Best L, Miley HE, Brown PD, Cook LJ (1999) Methylglyoxal causes swelling and activation of a volume-sensitive anion conductance in rat pancreatic $\beta$-cells. J Membr Biol 167:65-71

37. Sehlin $\mathrm{J}$ (1981) Are $\mathrm{Cl}^{-}$mechanisms in mouse pancreatic islets involved in insulin release? Ups J Med Sci 86:177182 